Article

\title{
Amino-Li-Resin-A Fiber Polyacrylamide Resin for Solid-Phase Peptide Synthesis
}

\author{
Damilola C. Akintayo ${ }^{1}\left(\mathbb{D}\right.$, Beatriz G. de la Torre ${ }^{2, *(\mathbb{D})}$, Yongfu $\mathrm{Li}^{3}$ and Fernando Albericio ${ }^{1,4,5, *(\mathbb{D})}$ \\ 1 Peptide Science Laboratory, School of Chemistry and Physics, University of KwaZulu-Natal, Westville, \\ Durban 4000, South Africa; damilolaakintayo141@gmail.com \\ 2 KwaZulu-Natal Research Innovation and Sequencing Platform (KRISP), School of Laboratory Medicine and \\ Medical Sciences, College of Health Sciences, University of KwaZulu-Natal, Durban 4041, South Africa \\ 3 Biotide Core, LLC, 33815 SE Eastgate Circle, Corvallis, OR 97333, USA; mail@biotide-core.com \\ 4 Institute for Advanced Chemistry of Catalonia (IQAC-CSIC), Jordi Girona 18-26, 08034 Barcelona, Spain \\ 5 CIBER-BBN, Networking Centre on Bioengineering, Biomaterials and Nanomedicine, Department of Organic \\ Chemistry, University of Barcelona, Martí i Franqués 1-11, 08028 Barcelona, Spain \\ * Correspondence: garciadelatorreb@ukzn.ac.za (B.G.d.l.T.); albericio@ukzn.ac.za (F.A.)
}

check for updates

Citation: Akintayo, D.C.; de la Torre, B.G.; Li, Y.; Albericio, F. Amino-Li-Resin-A Fiber

Polyacrylamide Resin for Solid-Phase Peptide Synthesis. Polymers 2022, 14, 928. https://doi.org/10.3390/ polym 14050928

Academic Editor: Antonio Pizzi

Received: 4 February 2022

Accepted: 21 February 2022

Published: 25 February 2022

Publisher's Note: MDPI stays neutral with regard to jurisdictional claims in published maps and institutional affiliations.

Copyright: (C) 2022 by the authors. Licensee MDPI, Basel, Switzerland. This article is an open access article distributed under the terms and conditions of the Creative Commons Attribution (CC BY) license (https:// creativecommons.org/licenses/by/ $4.0 /)$.

\begin{abstract}
Amino-Li-resin is a new and unique polyacrylamide resin presented in the form of fibers and is found to be well suited for solid-phase peptide chemistry. Although amino-Li-resin swells much better in polar solvents, it is also compatible with some non-polar solvents. It comes with a high loading of functional amino groups, thus maximizing its productivity in terms of the amount of peptide per gram of resin. In addition to its mechanical stability, this resin shows excellent stability in basic and acidic reagents; thus, allowing its broad applicability for the synthesis of a wide range of biomolecules. Finally, the appropriateness of amino-Li-resin for solid-phase peptide synthesis (SPPS) has been demonstrated for the synthesis of several model peptides, including difficult sequences and those containing hindered amino acids, all of which afforded excellent crude purity, as shown by high-performance liquid chromatography (HPLC) analysis.
\end{abstract}

Keywords: amino-Li-resin; solid-phase peptide synthesis; polyacrylamide; fibers

\section{Introduction}

The pioneering work of Bruce Merrifield [1], a Nobel Laureate, in developing a brilliant methodology for the synthesis of small to medium/large peptides on a laboratory and industrial scale $[2,3]$ has brought about untold possibilities for the application of peptides in science. This approach, known as solid-phase peptide synthesis (SPPS), effectively allows the preparation of peptides by anchoring the carboxylic end of an N-protected amino acid to a resin/solid support using excess reagents. The method involves a repetitive cycle of deprotection, coupling of successive amino acids in the C-N direction, and washing of unused reagents and by-products by filtration [4]. The combined use of excess reagents and the straightforward workup are key for the superior effectiveness of the strategy, as reflected by the excellent purity $(\geq 95 \%)$ of the crude peptides in a very short period.

The SPPS process is holistic and, therefore, its success depends on several factors, such as the resin [5-7], solvent (taking into consideration its polarity and viscosity) [8,9], coupling reagents [10-12], and protection scheme [13-17]. Despite the immense amount of work done over the years to improve these factors and thus facilitate the development of any kind of sequence, some "difficult peptide sequences" remain challenging [18,19]. In this regard, research efforts are ongoing to circumvent the many concerns that have arisen. The field has witnessed a considerable number of improvements, with the resin makeup being a major driving force. The resin, which contains a linker grafted onto an insoluble polymeric solid support, is critical for the effectiveness of any given synthetic procedure as it is central to the performance of the other factors. 
Industrially, polystyrene (PS)-based resins cross-linked with $1 \%$ of divinylbenzene is the solid support most widely used for SPPS. Polystyrene swells well in dichloromethane (DCM), the first solvent used in the seminal work of Merrifield. However, this solid support shows limited swelling capacity in polar solvents, which usually perform better for the synthesis of large peptides and there is a need to replace the hazardous DCM. More so, the high hydrophobicity of PS resulting from the high number of aromatic rings can cause $\pi-\pi$ interactions with other aromatic rings of the same resin or with those of the trityl protecting group, leading to extra cross-linking, thereby reducing the accessibility of reactive sites.

To overcome this drawback, PS resins with different cross-linking and, more importantly, different solid supports based on polyamides, polyacrylates, polyethylene glycol (PEG), and those obtained by grafting two of these materials were proposed to improve their applicability for a wide range of peptide targets and allow the use of other solvents, mostly green ones.

In 1973, Sheppard was the first to propose the massive use of dimethylformamide (DMF) as the solvent of choice for SPPS since this reagent resembles the growing peptide bond. In an attempt to change the paradigm (PS and DCM), he proposed that the joint use of DMF and a polar resin would most likely bring about a greater improvement in SPPS [20]. In this regard, his group embarked on the preparation of the first polydimethylacrylamide support by reacting dimethylacrylamide, 1,2-ethanediacrylamide, and a functionalized acrylamide-based monomer [21-23]. Fully beaded resins were obtained with a more hydrophilic monomer through a demarcated suspension polymerization methodology [22,24]. Several other acrylamide-based supports have since appeared in the literature for SPPS [25,26]. Worthy of note is the polyacrylamide resin (SPAR-50) developed by Sparrow $[27,28]$. SPAR-50 swells well in polar protic solvents and has been reported to produce peptides with high purity and better yields. However, its commercialization was later discontinued, possibly due to safety concerns as the synthetic process requires the use of $\mathrm{CCl}_{4}$ or DCM and other hazardous chemicals. Hence the need exists to revive the use of polyacrylamide-based resins using a greener approach (vide infra p. 4).

In the mid-1980s, two independent groups proposed poly(ethylene glycol)-PS-based resins designated PEG-PS by Barany, Albericio, and Zalipsky $[7,29]$ and TentaGel by Bayer and Rapp [30,31]. PEG-PS was obtained by amide formation between carboxylic acid-containing PEGs and amino-PS resins, whereas TentaGel was made by grafting PEG on PS beads. The superior performance of these two resins conferred by the addition of a hydrophilic polyether like PEG to the hydrophobic core of PS makes them compatible with polar and non-polar solvents. This feature has fueled the development of other PEG-PS resins, which, in most cases, have also been commercialized. Thus, Champion I and II (designated as Novagel) were prepared by the incorporation of linear blocks and branched-chain PEGs, respectively [32]. ArgoGel was obtained by attaching PEG to branched diol supports [33], OctaGel has its sites capped with PEG and the surface solely containing the reactive site, thus giving it a high degree of uniformity [5].

The modification of PEG on the PS core in all these resins tends to confer relatively uniform swelling in a variety of solvents, ranging from toluene to $\mathrm{H}_{2} \mathrm{O}$, and good performance for the synthesis of a broad number of peptides. However, these modified resins have the following disadvantages: (i) low loading $(0.2-0.4 \mathrm{mmol} / \mathrm{g}$ ); (ii) leaching: and (iii) high cost. PEG is usually linked to the PS by an acid-labile bond, which can be released during the final acidic cleavage step. This release will compromise the purity or content of the final peptide because PEG will also precipitate during the work-up with ether. The modification process adds to the manufacturing complexity and cost due to its small production scale. Moreover, industrial applications require the use of large batches (multi-Kgs) of resins, which are often extremely costly.

PEG-based resins containing minute quantities of functionalities, such as polyamide, PS [34-36], and acrylate with polymerizable vinyl moiety [37-39], have been reported. PEGA is a flow-stable and highly branched PEG-based resin prepared by the copolymerization of bisacrylamidoprop-1-yl-PEG 1900,2 -acrylamidoprop-1-yl[2-aminoprop-1-yl]-PEG 300 , 
and $\mathrm{N}, \mathrm{N}$-dimethyl acrylamide. This highly polar support prepared by a simple synthetic procedure using inexpensive starting material was designed to facilitate peptide solvation for the synthesis of long peptides. Cross-linked-ethoxylate-acrylate-resin (CLEAR) is another highly cross-linked PEG-based resin prepared either by bulk or suspension processes and involving the copolymerization of trimethylolpropane ethoxylate cross-linkers with readily available monomers in a single step. This class of solid support demonstrated good swelling properties in common solvents and has been reported to be highly stable for SPPS protocols. However, it may be unstable in specific strong bases.

Eventually, Meldal and his group [40,41] and Cote [6,42] independently reported a completely PEG-based resin, namely ChemMatrix (CM). CM has been widely used in SPPS, especially for long and difficult peptides [43-45]. The vicinal arrangement of carbon-oxygen bonds throughout the chain makes the resin amphiphilic and, as such, it is well-solvated in a wide range of solvents. CM is superior to other reported resins in terms of the purity of the final peptide, mechanical strength, and chemical stability in diverse reagents. However, it is expensive and difficult to produce on a large scale. Furthermore, it has got a poor recovery, and it requires extra solvents to drive the reaction to completion.

To facilitate the solid-phase synthesis of a large range of peptides and at the same time overcome the issues associated with the resins already on the market, we have continuously pursued new polar resins with good swelling capacity $(\geq 4 \mathrm{~mL} / \mathrm{g})$ in a broad number of solvents $[8,46]$. In our endeavors, we studied the second generation of amino-polyacrylamide resin (amino-Li-resin) designed and developed by Yongfu Li.

In this regard, we examined the swelling capacity, morphology, chemical stability, and synthetic performance of this resin for the synthesis of several model peptides. To this end, Fmoc-Rink-Amide-Li-resin was used to synthesize the following sequences, which were encountered as difficult sequences or sequences containing hindered amino acids: leu-enkephalin (H-YGGFL- $\left.\mathrm{NH}_{2}\right)$; $\mathrm{Ile}^{2}$, Ile $^{3}$-leu-enkephalin (H-YIIFL- $\left.\mathrm{NH}_{2}\right)$; RGD peptide (H-RGDfK-NH $\left.\mathrm{H}_{2}\right) ;{ }^{6} \mathrm{Gly}^{65-74} \mathrm{ACP}$ (H-VGAAIDYING-NH${ }_{2}$ ), and a modified decaalanine (H-AAAAAAAAAAKKK- $\mathrm{NH}_{2}$ ) to test its utility.

\section{Experimental Section}

\subsection{Materials and Methods}

Amino-Li-resin was provided by Biotide Core, LLC, Corvallis, OR, USA. All reagents and solvents for this study were obtained commercially and used without further purification. Piperidine, acetonitrile (HPLC grade), dimethyl formamide and other organic solvents used were purchased from Merck Life Science (Pty) Ltd., Modderfontein, South Africa; and the Fmoc amino acids were obtained from Iris Biotech, Marktredwitz, Germany. Infrared (IR) spectra were obtained on a PerkinElmer Universal ATR spectrum 100 Fourier transform infrared (FT-IR) spectrometer. The high-performance liquid chromatography (HPLC) analysis was conducted on a reversed-phase $C_{18}$ column $(4.6 \mathrm{~mm} \times 150 \mathrm{~mm}$, $3.6 \mu \mathrm{m})$ at a flow rate of $1.0 \mathrm{~mL} / \mathrm{min}$, using linear gradients of $4.5 \times 10^{-2} \%$ Trifluoroacetic acid (TFA) and $3.6 \times 10^{-2} \%$ acetonitrile $(\mathrm{ACN})$. High-performance liquid chromatography /mass spectrometry (HPLC/MS) was also obtained on a reversed-phase $\mathrm{C}_{18}$ column $(4.6 \mathrm{~mm} \times 150 \mathrm{~mm}, 3.6 \mu \mathrm{m})$ by means of aqueous $(0.1 \%)$ formic acid and formic acid $(0.07 \%)$ in can, as eluents.

\subsection{Swelling Capacity}

$0.2 \mathrm{~g}$ of resin was added to a $5 \mathrm{~mL}$ syringe fitted with a $0.45 \mu \mathrm{m}$ filter and furnished with sufficient solvent to give a final volume of $5 \mathrm{~mL}$ for $5-10 \mathrm{~min}$ to allow the resin to swell to maximum capacity. The piston of the syringe was used to compress the swollen resin to completely drain off the solvent, after which it was carefully drawn until the resin recovered its highest volume, which was then measured. By averaging the void volume of the tip and the syringe to be $0.15 \mathrm{~mL}$, the swelling was determined using Equation (1):

$$
\text { Swelling }(\mathrm{mL} / \mathrm{g})=\frac{\text { volume of the swelled resin }-0.15 \mathrm{~mL}}{0.2 \mathrm{~g}}
$$




\subsection{Preliminary Washing}

Amino-Li-resin was subjected to preliminary treatment by washing three times using $5 \% \mathrm{~N}, \mathrm{~N}$-diisopropylethylamine (DIEA)/DCM (1 min) to neutralize any acid present. Afterwards, it was washed twice with DCM (1 min) and finally washed thrice with DMF (1 min) before it was used for the synthesis of the model peptides.

\subsection{Peptide Synthesis}

All operations involving the manual synthesis and peptide elongation were done in polypropylene syringes equipped with a permeable polyethylene disk. The synthetic protocol adopted involves the removal of soluble chemical reagents and all solvents through suction. The manual synthesis of the chosen model peptides was done using Fmoc-Rink-amide Liresin $(0.1 \mathrm{mmol}$ scale, loading $0.8 \mathrm{mmol} / \mathrm{g})$ at ambient temperature. The deprotection step (Fmoc removal) was carried out using $20 \%$ piperidine in dimethylformamide $(1 \times 1 \mathrm{~min}$, $2 \times 10 \mathrm{~min}$ ), while other intermediate washing steps between each amino acid coupling and subsequent Fmoc removal was accomplished with dimethylformamide $(5 \times 1 \mathrm{~min})$ and dichloromethane $(5 \times 1 \mathrm{~min})$ using $10 \mathrm{~mL}$ of solvent per gram of resin. At room temperature, the peptidyl resin was dried under vacuum and subjected to a global deprotection and cleavage for 60 min using a freshly prepared cocktail (95\% trifluoroacetic acid (TFA): $2.5 \%$ tri-isopropylsilane (TIS): $2.5 \% \mathrm{H}_{2} \mathrm{O}$ ). The crude peptide was crashed out using cold diethyl ether. The solution was then centrifuged, and the solvent was carefully decanted. The precipitation and cleaning processes were repeated three times, after which, the crude peptides were analyzed by HPLC and HPLC/MS using the following HPLC gradients: $5-60 \%$ B into A in 15 min for H-Tyr-Gly-Gly-Phe-Leu-NH ${ }_{2}$ and H-Tyr-Ile-Ile-Phe-Leu- $\mathrm{NH}_{2}, 5-95 \%$ B into A in 15 min for H-Arg-Gly-Asp-DPhe-Lys- $\mathrm{NH}_{2}$, H-Val-Gly-Ala-Ala-Ile-Asp-Tyr-Ile-Asn-Gly- $\mathrm{NH}_{2}$, and H-Ala-Ala-Ala-Ala-Ala-Ala-Ala-Ala-Ala-Ala-Lys-Lys-Lys- $\mathrm{NH}_{2}$.

\section{Results and Discussion}

\subsection{Preparation}

Amino-Li-resin was prepared by polymerization using $N, N$-dimethylacrylamide as a monomer, $N, N^{\prime}$-bis(acryloyl)piperazine as cross-linker, 1-[1-( $N$-acrylyl)piperidin-4yl]methanamine as functionalizing moiety, and $N, N, N^{\prime}, N^{\prime}$-tetramethylethylenediamine (TEMED) as initiator [47], following an in house proprietary fiberization technology (Figure 1). The use of a rather high proportion of $N, N^{\prime}$-bis(acryloyl)piperazine makes the final resin highly cross-linked, thus conferring high mechanical stability. The proportions of the different reagents were calculated to afford a loading of $0.8 \mathrm{mmol}$ of amino per gram of resin.

An advantage of the amino-Li-resin in comparison with amino-PS resins is that the 4-(aminomethyl)piperidin-1-yl functionalization, an aliphatic amine, is more reactive than the benzylamine or benzhydrylamine in the case of PS resins. This is important because the first reaction involves the incorporation of a linker, which is often an expensive reagent, through an amide bond. Furthermore, this amide bond will be more acid-stable than the amide bond formed by the same linker and amino-PS resins, thus preventing the formation of side products during the final global deprotection and cleavage step [48].

\subsection{Physical Properties}

Scanning electron microscope (SEM) images of amino-Li-resin (Figure 2a-d) confirmed the formation of fibers as different from the regular spherical beads observed with prominent resins like PS, PEG-PS, CLEAR, and CM (Figure 3a-d). Spherical beads are normally between 150 to 300 microns in diameter, whereas the fiber of amino-Li-resin is 150 microns in diameter and about 400 microns in length. The SEM images of amino-Li-resin fiber revealed a porous microstructure with a larger surface area, allowing for superior penetration of reagents and solvents over the beaded resins. 


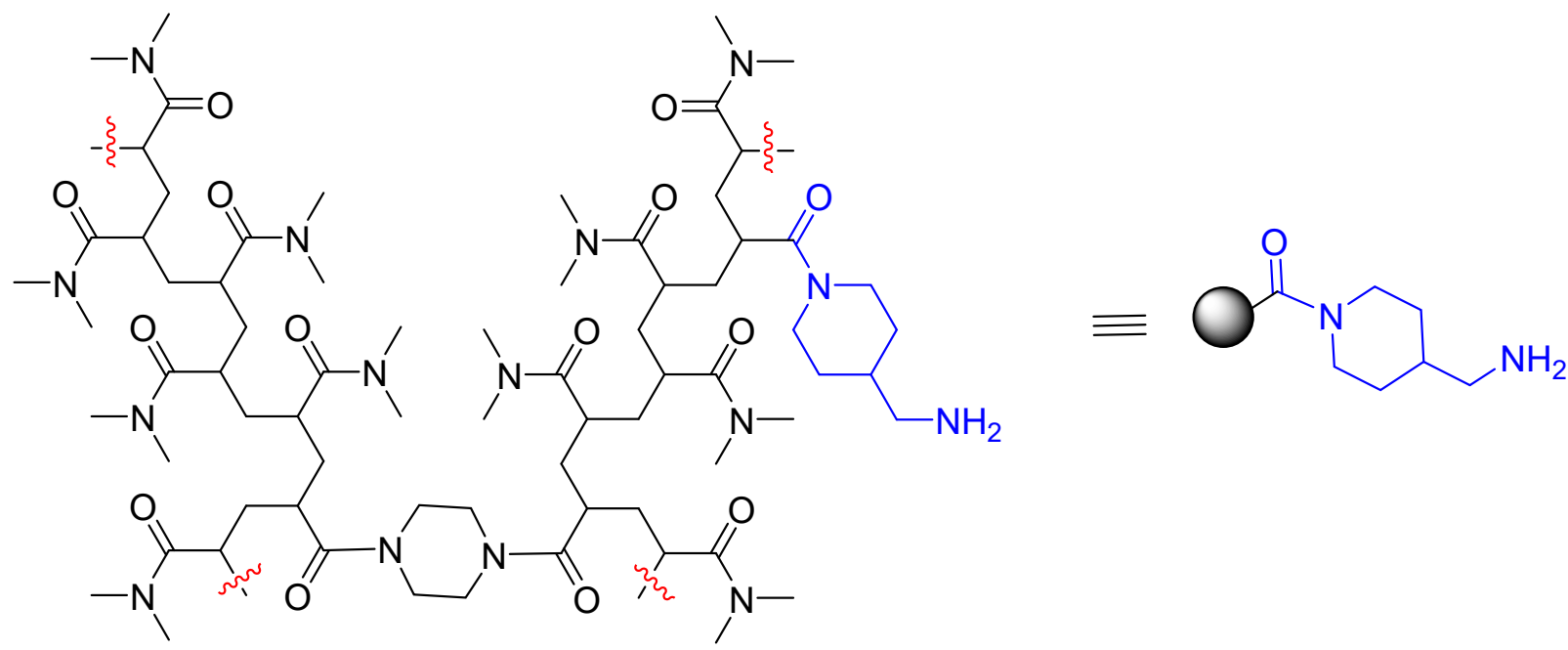

Figure 1. Chemical structure of amino-Li-resin prepared from $N, N$-dimethylacrylamide as a monomer, $N, N^{\prime}$-bis(acryloyl)piperazine as cross-linker, 1-[1-( $N$-acrylyl)piperidin-4-yl]methanamine as functionalizing moiety, and $N, N, N^{\prime}, N^{\prime}$-tetramethylethylenediamine as initiator.

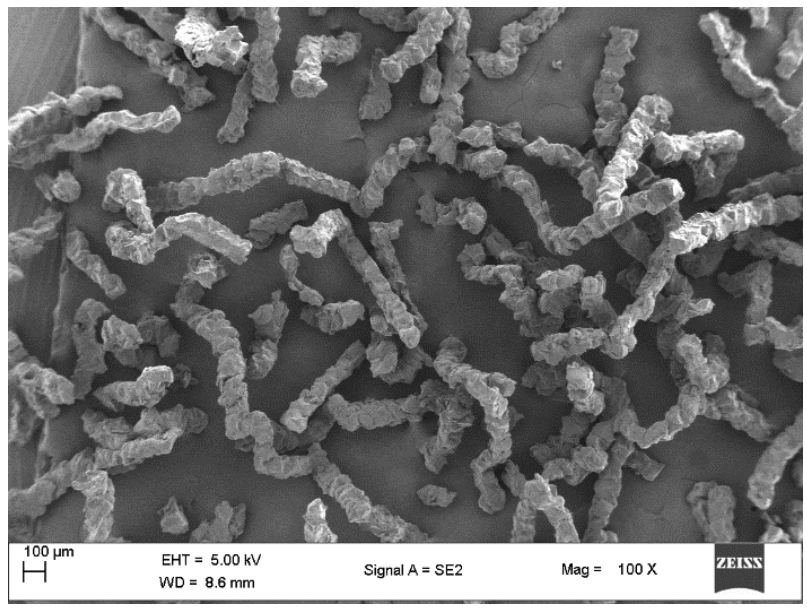

(a)

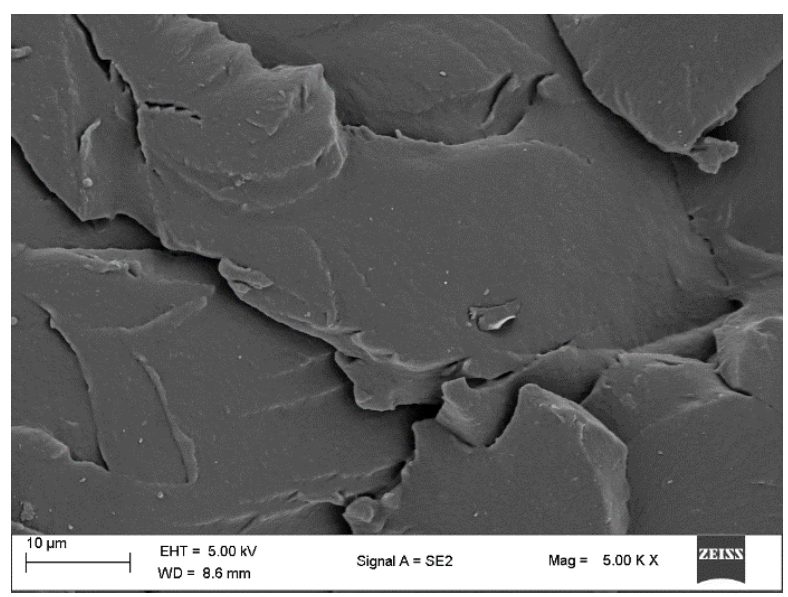

(c)

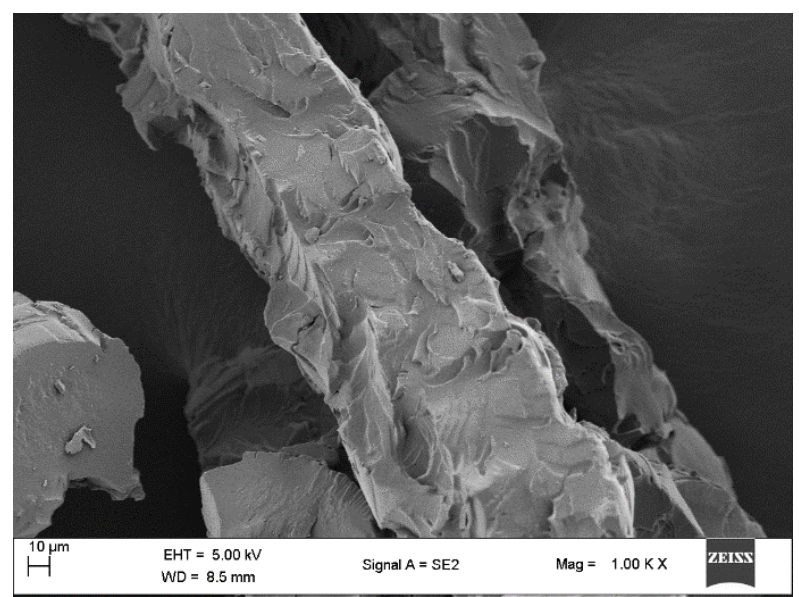

(b)

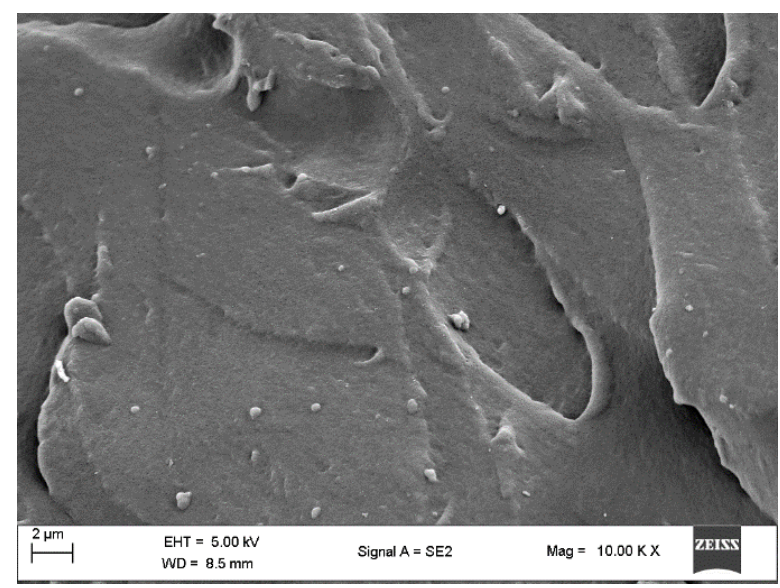

(d)

Figure 2. SEM images of amino-Li-resin: (a) $100 \mu \mathrm{m}(100 \mathrm{X}),(\mathbf{b}) 10 \mu \mathrm{m}(1.00 \mathrm{~K} \mathrm{X}),(\mathbf{c}) 10 \mu \mathrm{m}(5.00 \mathrm{~K} \mathrm{X})$, and (d) $2 \mu \mathrm{m}(\mathrm{Mag}=10.00 \mathrm{KX})$. 


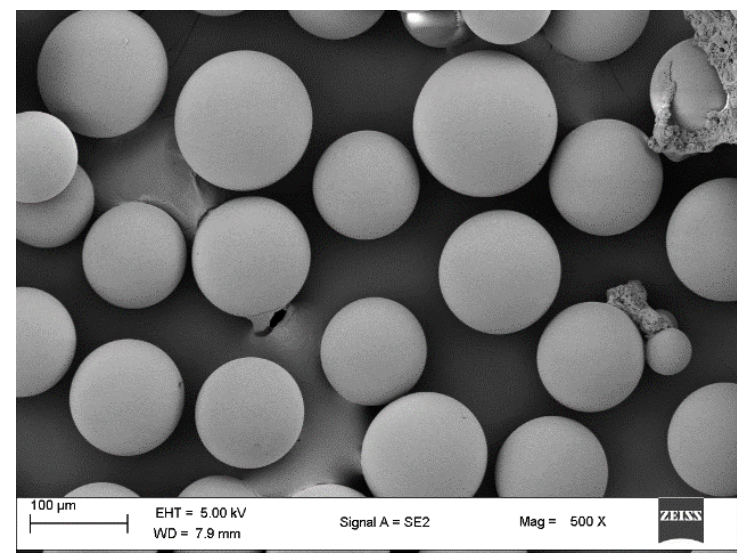

(a)

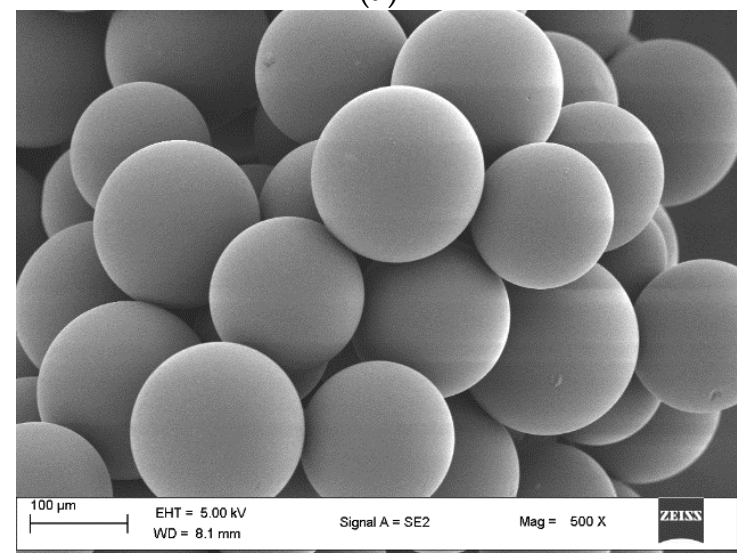

(c)

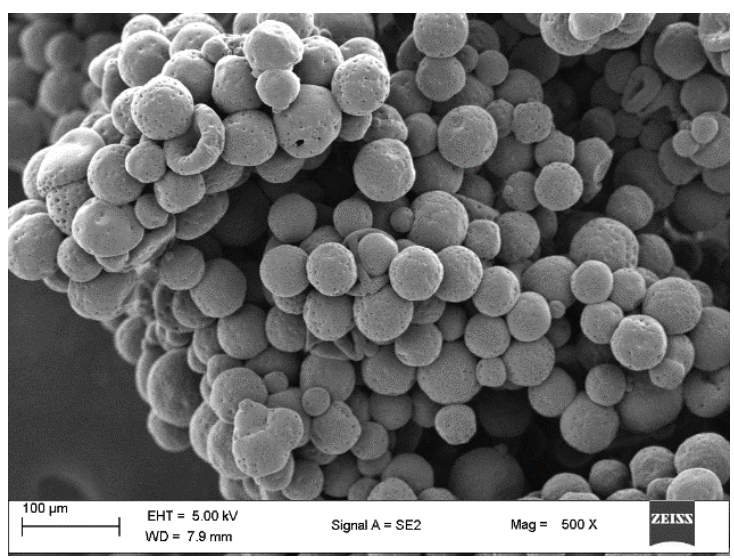

(b)

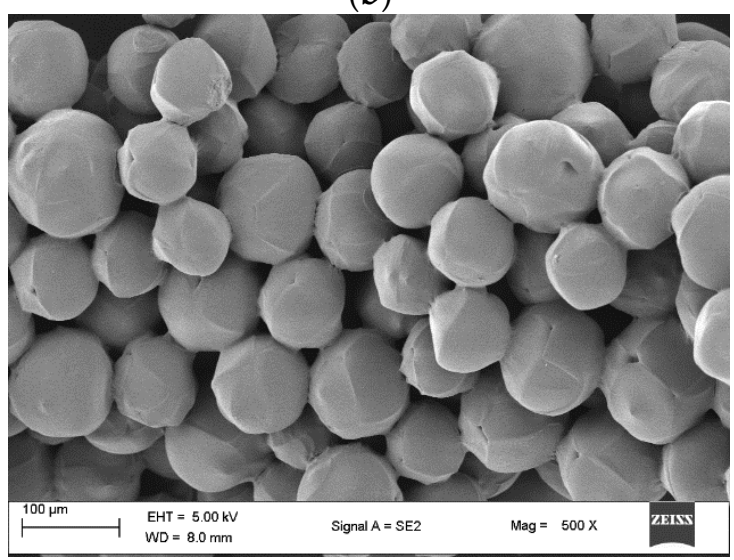

(d)

Figure 3. SEM images of (a) PS, (b) PEG-PS, (c) CLEAR, and (d) CM taken at $100 \mu \mathrm{m}$ and magnification of 500 .

The polyacrylamide-based resin was examined by infrared spectroscopy (IR) after overnight treatment in a range of reagents used in SPPS, including acids and bases. Diagnostic peaks corresponding to the amide moiety observed between $3100 \mathrm{~cm}^{-1}$ and $3500 \mathrm{~cm}^{-1}$ for the N-H stretch and between $1610 \mathrm{~cm}^{-1}$ and $1700 \mathrm{~cm}^{-1}$ for the $\mathrm{C}=\mathrm{O}$ stretch was used to evaluate its stability. Amino-Li-resin was relatively stable in organic reagents (Figure 4a), as well as in hydrochloric acid $(\mathrm{HCl})$ at all the concentrations tested (Figure 4c). It retained its chemical stability after treatment in $20 \%$ piperidine in DMF and $100 \%$ TFA used for deprotection and global cleavage, respectively. All spectra results showed no observable changes between the treated resins and the untreated ones (designated as original in Figure $4 \mathrm{a}-\mathrm{c}$ ); thus, confirming its chemical stability and broad compatibility.

\subsection{Swelling}

A primary consideration for the suitability of any given resin in SPPS is its swelling capacity. This is an important property since it indicates the availability of the resin to interact with a variety of solvents and common reagents. The swelling capacity of amino-Li-resin was compared with that of PS, PEG-PS, CM, and CLEAR resins in a broad range of solvents, including protic and non-protic polar solvents, and also green solvents (Table 1, Figure 5a,b). 


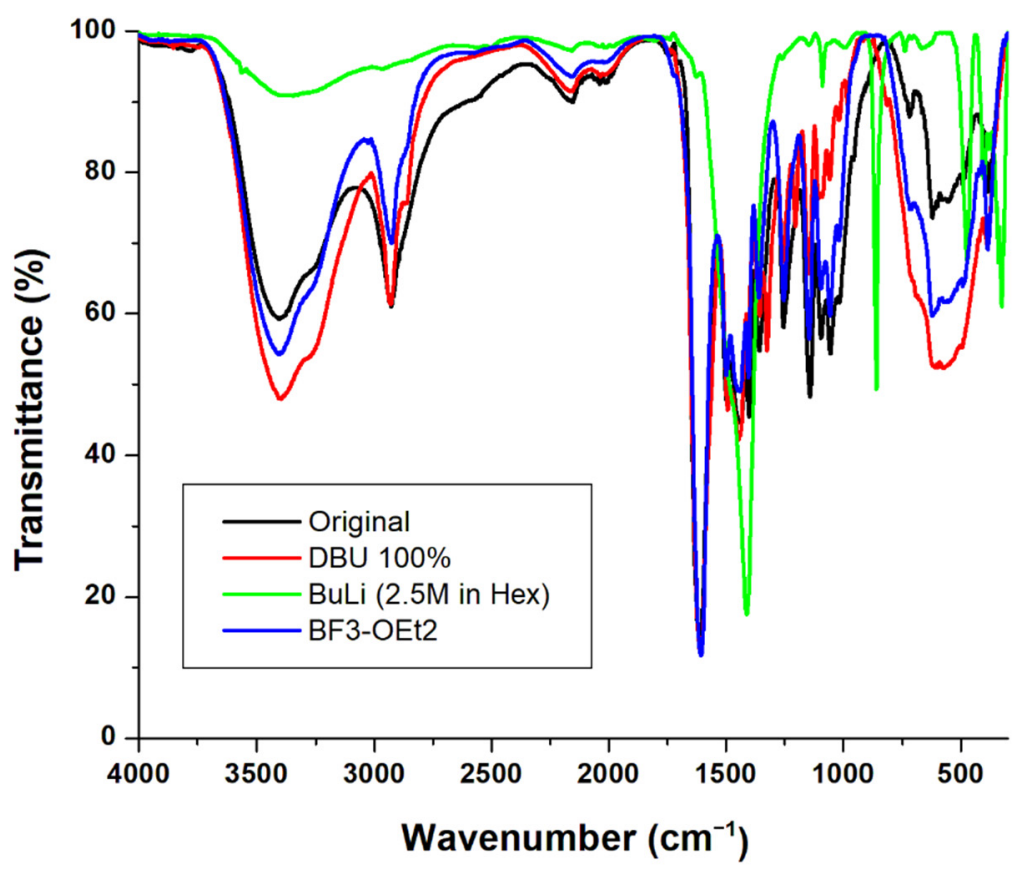

(a)

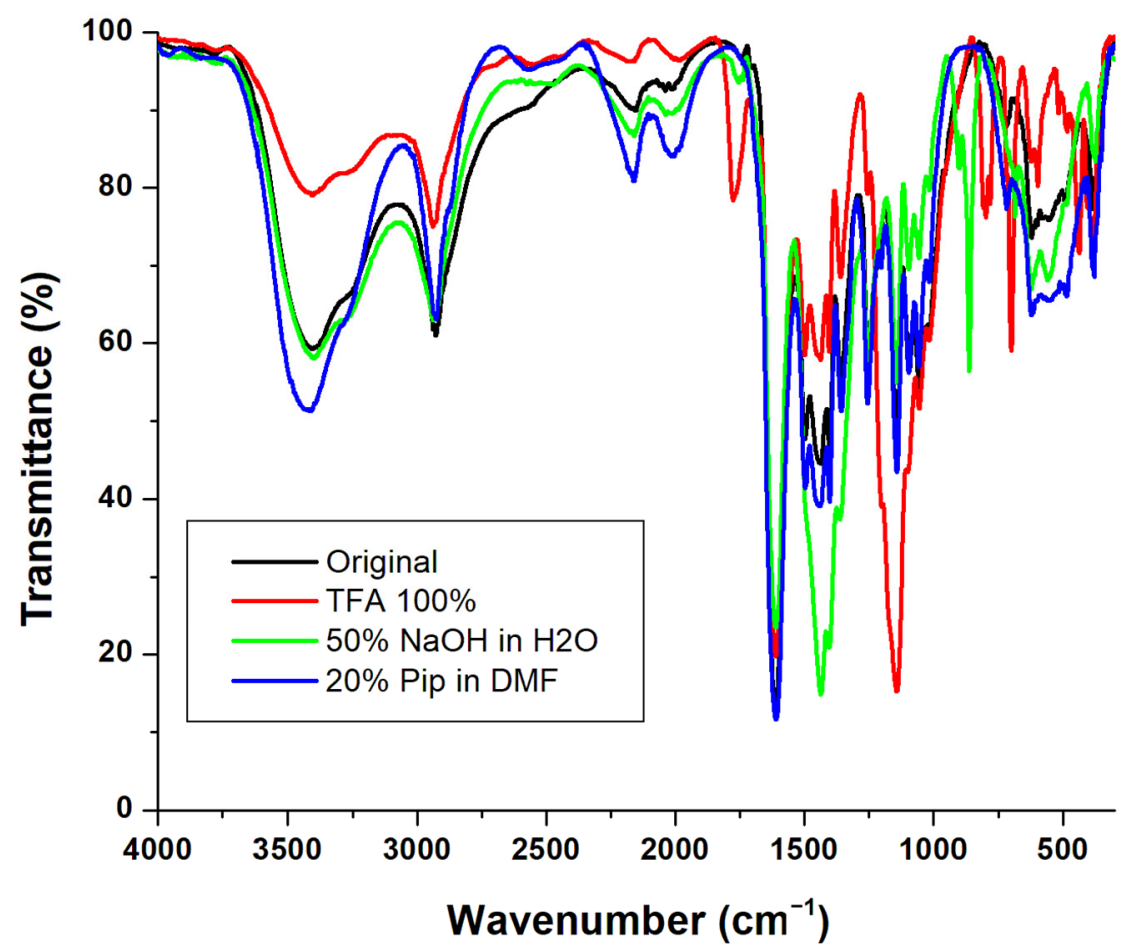

(b)

Figure 4. Cont. 


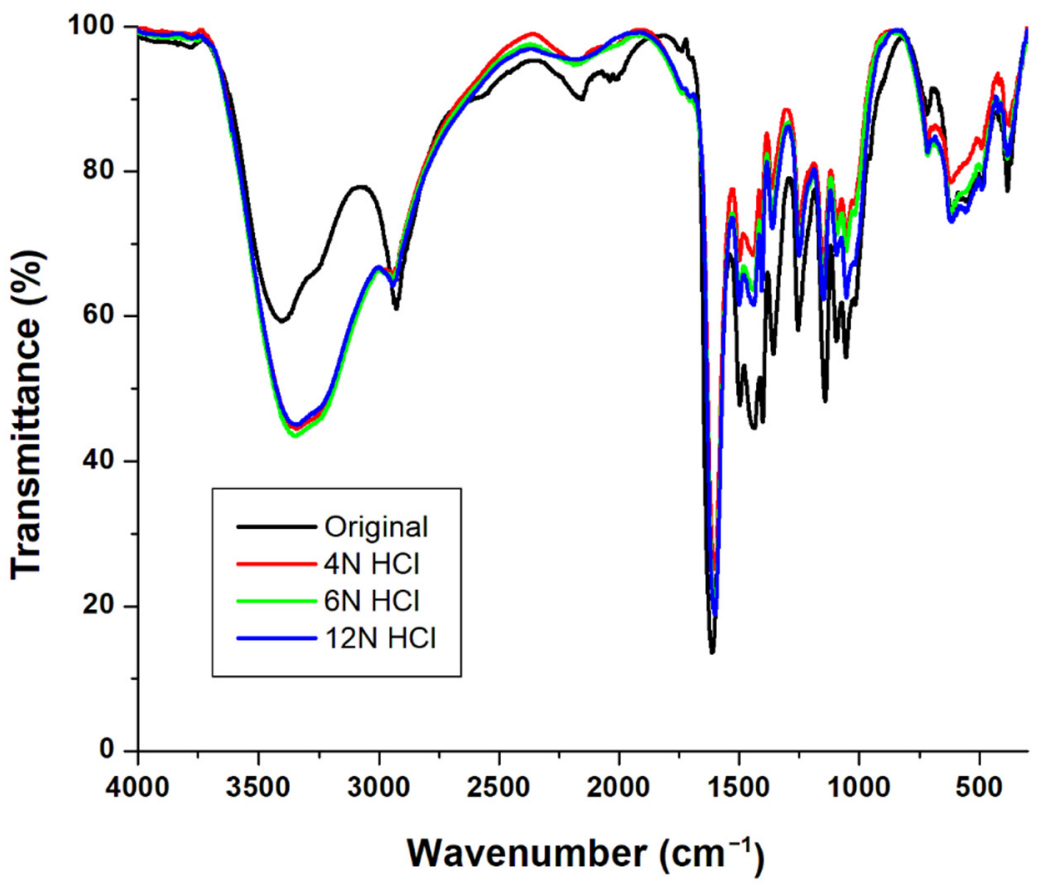

(c)

Figure 4. IR spectra of amino-Li-resin after overnight treatment in (a) $100 \% \mathrm{DBU}_{1} \mathrm{BF}_{3}-\mathrm{OEt}_{2}$ and untreated resin, (b) $100 \%$ TFA, $50 \% \mathrm{NaOH}$ in $\mathrm{H}_{2} \mathrm{O}, 20 \%$ piperidine in DMF and untreated resin, and (c) $4 \mathrm{~N}, 6 \mathrm{~N}$, and $12 \mathrm{~N} \mathrm{HCl}$ and untreated resin.

Table 1. Swelling of the selected resins in green and non-green solvents.

\begin{tabular}{|c|c|c|c|c|c|c|}
\hline \multirow{2}{*}{ Entry (\#) } & \multirow{2}{*}{ Solvent } & \multicolumn{5}{|c|}{ Swelling (mL/g) } \\
\hline & & Li-resin & PS & PEG-PS & CM & CLEAR \\
\hline 1 & DMF & 5.75 & 4.75 & 4.25 & 8.25 & 3.25 \\
\hline 2 & DCM & 7.75 & 5.25 & 5.25 & 10.75 & 3.75 \\
\hline 3 & $\mathrm{H}_{2} \mathrm{O} *$ & 6.75 & 1.75 & 1.75 & 8.25 & 2.25 \\
\hline 4 & $\mathrm{MeOH}$ & 10.25 & 2.75 & 2.75 & 9.75 & 3.25 \\
\hline 5 & IPA * & 8.5 & 1.75 & 1.75 & 2.25 & 2.25 \\
\hline 6 & $\mathrm{ACN}$ & 4.25 & 1.75 & 3.25 & 8.25 & 3.25 \\
\hline 7 & DMSO * & 6.25 & 6.25 & 3.75 & 8.25 & 3.25 \\
\hline 8 & GVL * & 4.25 & 3.25 & 4.25 & 9.25 & 3.25 \\
\hline 9 & NFM * & 5.25 & 2.75 & 3.75 & 8.25 & 3.25 \\
\hline 10 & $\mathrm{NBP} *$ & 2.75 & 6.25 & 4.25 & 2.75 & 3.25 \\
\hline 11 & 2-Me-THF * & 2.25 & 4.25 & 2.75 & 2.25 & 2.75 \\
\hline 12 & AcOEt * & 2.25 & 2.75 & 2.75 & 6.25 & 2.75 \\
\hline 13 & Polar Clean * & 2.25 & 2.25 & 3.75 & 7.25 & 3.25 \\
\hline 14 & CPME * & 2.25 & 3.75 & 2.25 & 3.25 & 2.75 \\
\hline 15 & $\left(\mathrm{CH}_{3} \mathrm{O}\right)_{2} \mathrm{CO}$ & 3.25 & 3.25 & 2.75 & 9.25 & 3.75 \\
\hline 16 & Anisole * & 2.75 & 4.25 & 3.75 & 11.25 & 3.25 \\
\hline 17 & 1,3-DMB * & 2.25 & 4.25 & 3.75 & 10.25 & 3.25 \\
\hline 18 & $\begin{array}{c}\text { 1,3-DMB-NFM } \\
(3: 1)^{*}\end{array}$ & 3.75 & 4.25 & 4.25 & 10.25 & 4.25 \\
\hline 19 & NBP-AcOEt $(1: 4) *$ & 3.25 & 5.75 & 3.75 & 9.25 & 3.75 \\
\hline 20 & TFA & 11.25 & 2.25 & 5.75 & 15.25 & 5.75 \\
\hline
\end{tabular}

$\mathrm{MeOH}$, Methanol; IPA, Isopropanol; ACN, Acetonitrile; DMSO, Dimethyl sulphoxide; GVL, gamma-Valerolactone NFM, N-Formylmorpholine; NBP, N-Butyl-2-pyrrolidone; 2-Me-THF, 2-methyltetrahydrofuran; AcOEt, Ethyl acetate; CPME, cyclopentyl methyl ether; $\left(\mathrm{CH}_{3} \mathrm{O}\right)_{2} \mathrm{CO}$, Dimethylcarbonate; 1,3-DMB, 1,3-Dimethylbenzene; TFA, Trifluoroacetic acid; * Green Solvent. 


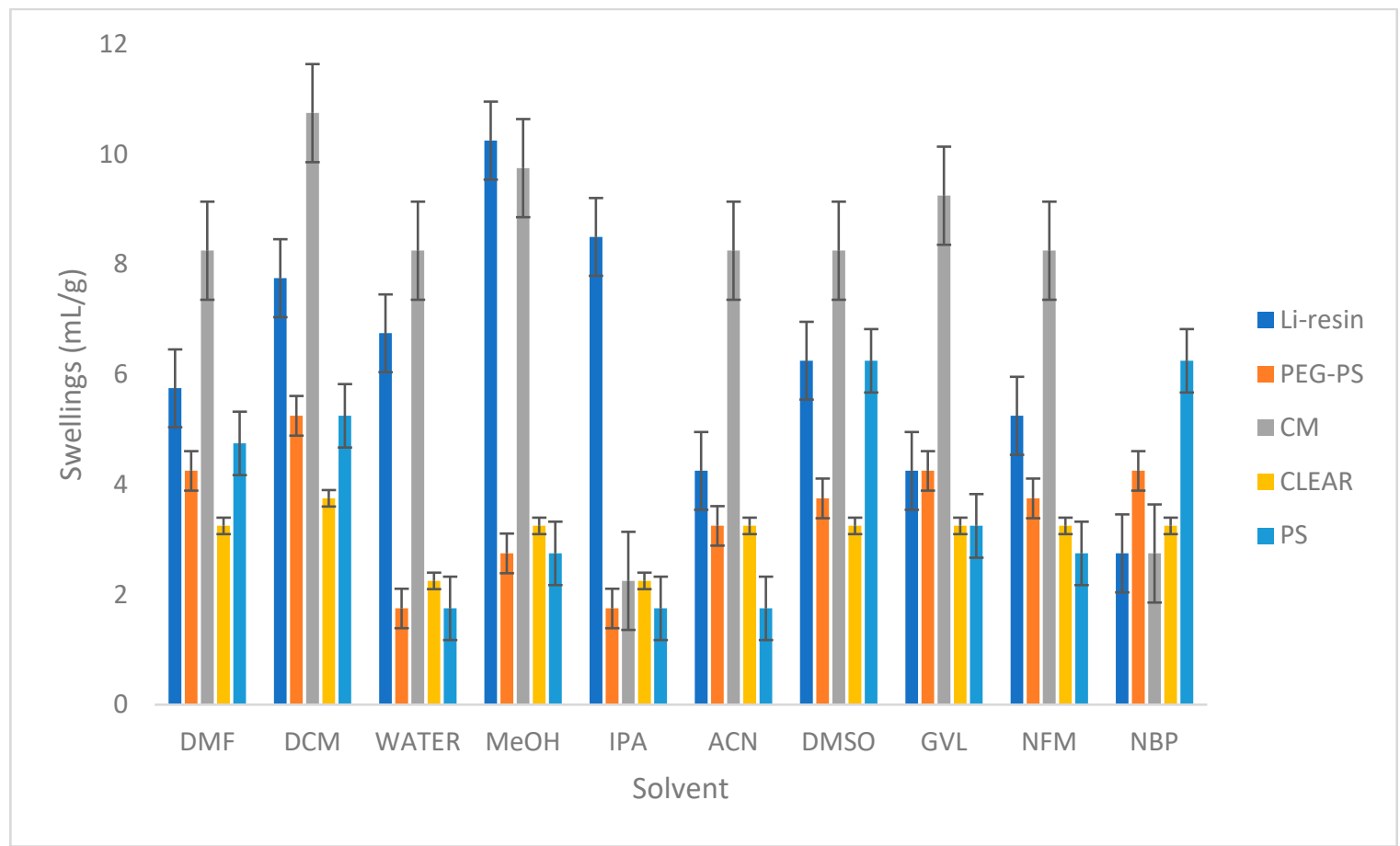

(a)

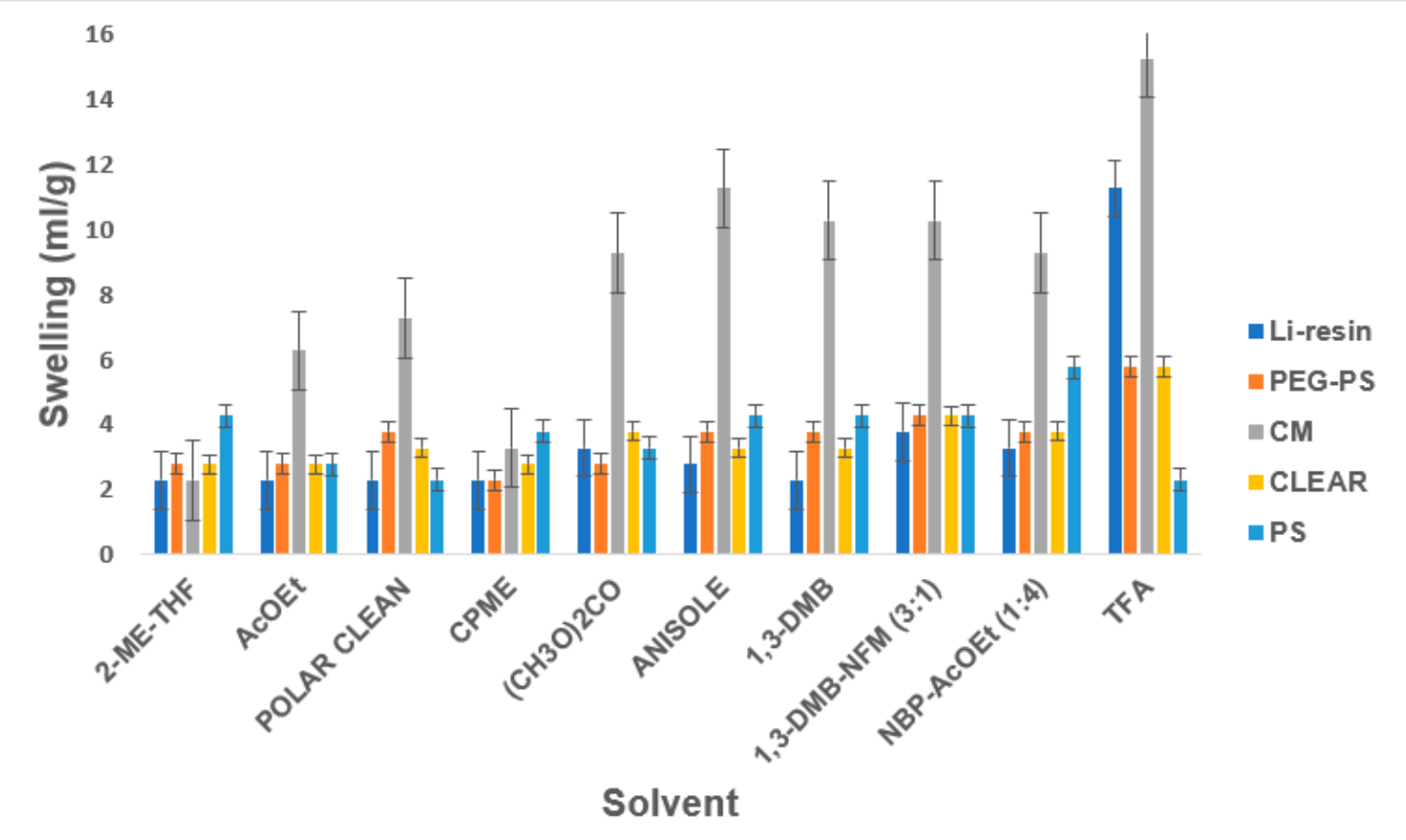

(b)

Figure 5. (a,b) Swelling of resins in different solvents.

Amino-Li-resin swelled better than PS and PEG-PS but a little less than CM in DMF (\#1), which is the most used solvent for SPPS both in research and industry. Although DMF is not a green solvent, it can be beneficial since it brings about enhanced swelling with respect to PS, but without a disproportionate increase in the consumption of solvents in the different steps of SPPS, particularly in the washes. In DCM (\#2), which is considered more hazardous than DMF, the same trend was observed. Generally, amino-Li-resin swelled well in protic polar solvents such as $\mathrm{H}_{2} \mathrm{O}(\# 3), \mathrm{MeOH}(\# 4)$, and IPA (\#5), this making this support highly suitable for biochemical assays involving these solvents [49]. Interestingly, 
Li-resin swelled well in ACN (\#6), which is a solvent specifically indicated to be useful for difficult couplings $[9,18]$.

With the advent of the mandate of greening all chemical processes, including SPPS, resin compatibility with green solvents is a plus [50]. In this regard, amino-Li-resin showed good swelling in DMSO (\#7), GVL (\#8), and NFM (\#9), the latter considered a green analog of DMF. However, its swelling capacity in NBP (\#10) was lower than in the previous solvents. In other green solvents (\#11-14), including two aromatics (anisole \#16 and 1,3-DMB \#17), the resin showed the same degree of swelling. Furthermore, swelling in mixtures of green solvents [1,3-DMB-NFM (3:1) \#18 and NBP-AcOEt (1:4) \#19] was acceptable in both cases. Finally, in TFA (\#20), which is the reagent used for the final global deprotection and cleavage, the swelling of amino-Li-resin was lower than in CM, which is also good for avoiding extra consumption of this reagent.

Given the interesting physical characteristics of amino-Li-Resin, it was used for the synthesis of selected model peptides using the standard fluorenylmethoxycarbonyl (Fmoc)/tert-butyl (tBu) protocol, by means of $N, N^{\prime}$-diisopropylcarbodiimide (DIC)-OxymaPure as coupling method at room temperature. We started the evaluation with the manual synthesis of the model Leu-enkephalin peptide (H-YGGFL- $\mathrm{NH}_{2}$ ) using the Rink-amide-Li-resin. At the end of the peptide elongation, the pentapeptide was successfully cleaved with TFA- $\mathrm{H}_{2} \mathrm{O}-\mathrm{TIS}$ (95:2.5:2.5), precipitated with ether, lyophilized, and analyzed on HPLC, giving $100 \%$ purity (Figure 6). The efficacy of the Rink-amide-Li-resin was further examined in a more hindered pentapeptide where the two Gly residues were replaced by Ile (H-YIIFL- $\left.\mathrm{NH}_{2}\right)$ and again afforded $100 \%$ purity, as reflected by the HPLC analysis (Figure 7). The RGD peptide (H-RGDfK- $\mathrm{NH}_{2}$ ), which gave $97 \%$ purity from HPLC analysis (Figure 8 ) is comparable with RGD analogues prepared with 2-chlorotrityl resin [51].

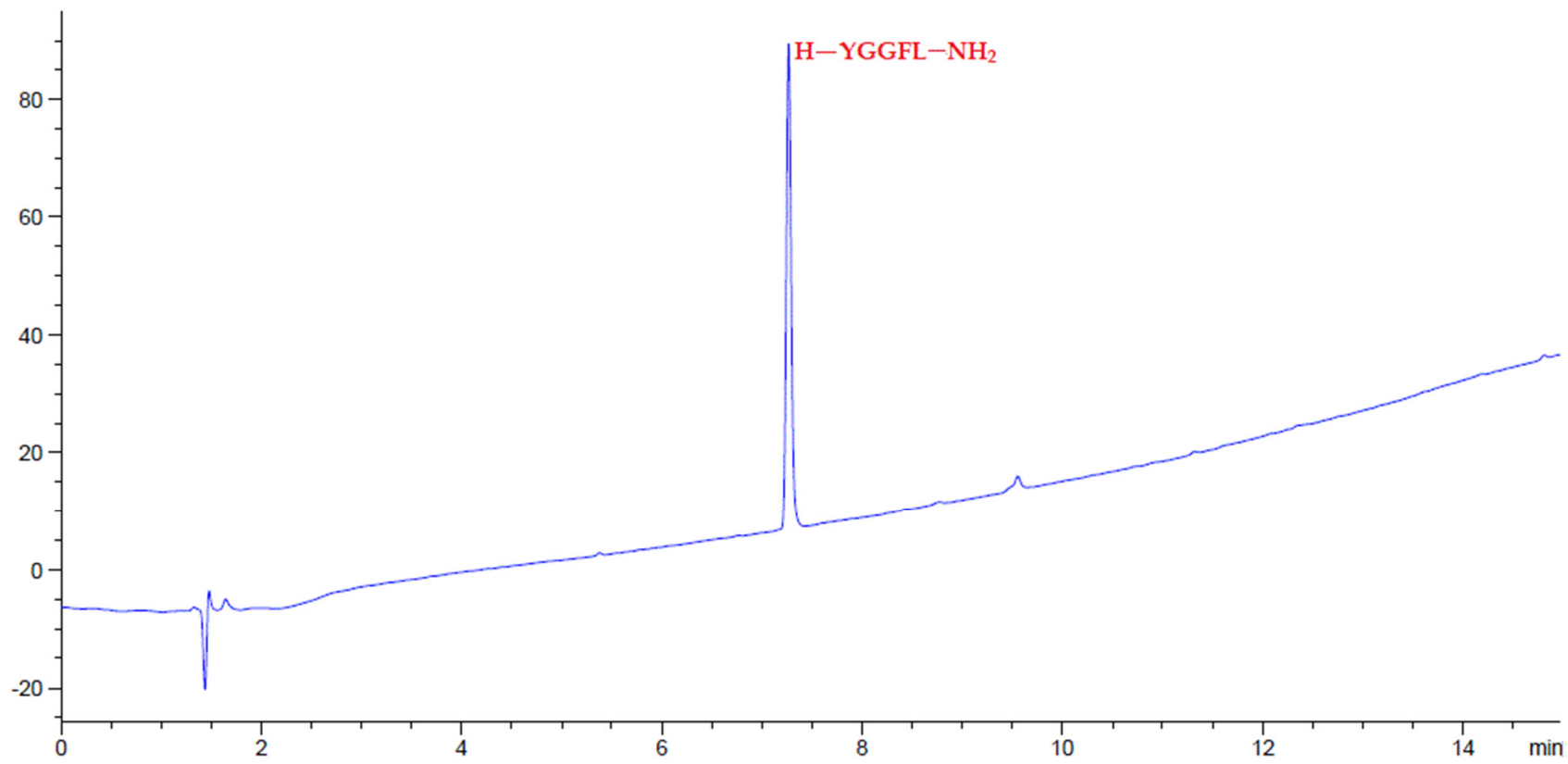

Figure 6. HPLC chromatograms of crude peptides H-YGGFL-NH $\mathrm{N}_{2}$ after precipitation.

Following the excellent purity of the model pentapeptides obtained from HPLC, we proceeded to synthesize other demanding peptide sequences like ${ }^{66} \mathrm{Gly}-{ }^{65-74} \mathrm{ACP}$ (H-VGAAIDYING-NH $\mathrm{N}_{2}$ ), which gave a purity of $>95 \%$, with the most important impurity being the deletion of Val (Figure 9). 


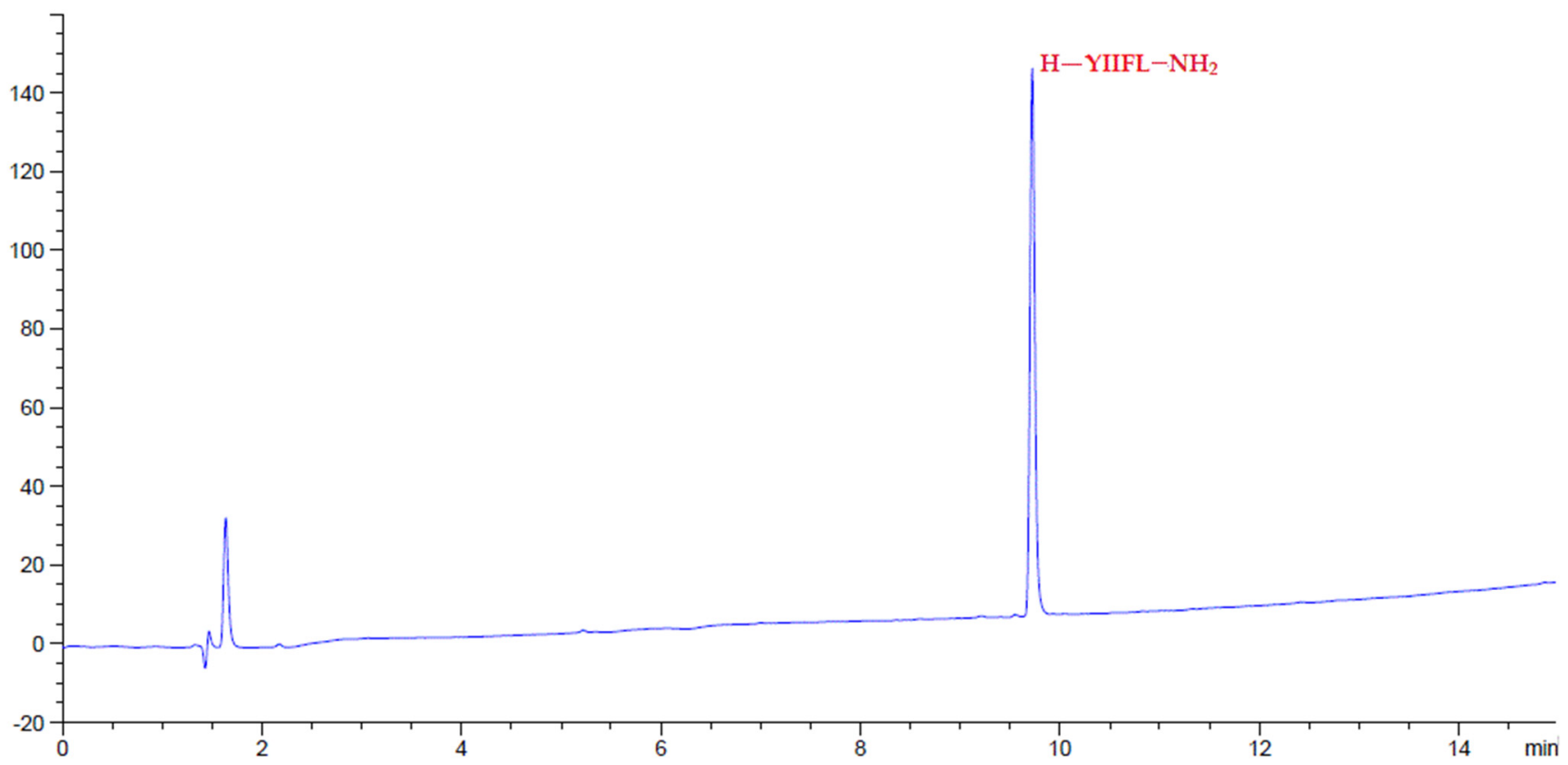

Figure 7. HPLC chromatograms of crude peptides $\mathrm{H}-\mathrm{YIIFL}-\mathrm{NH}_{2}$ after precipitation.

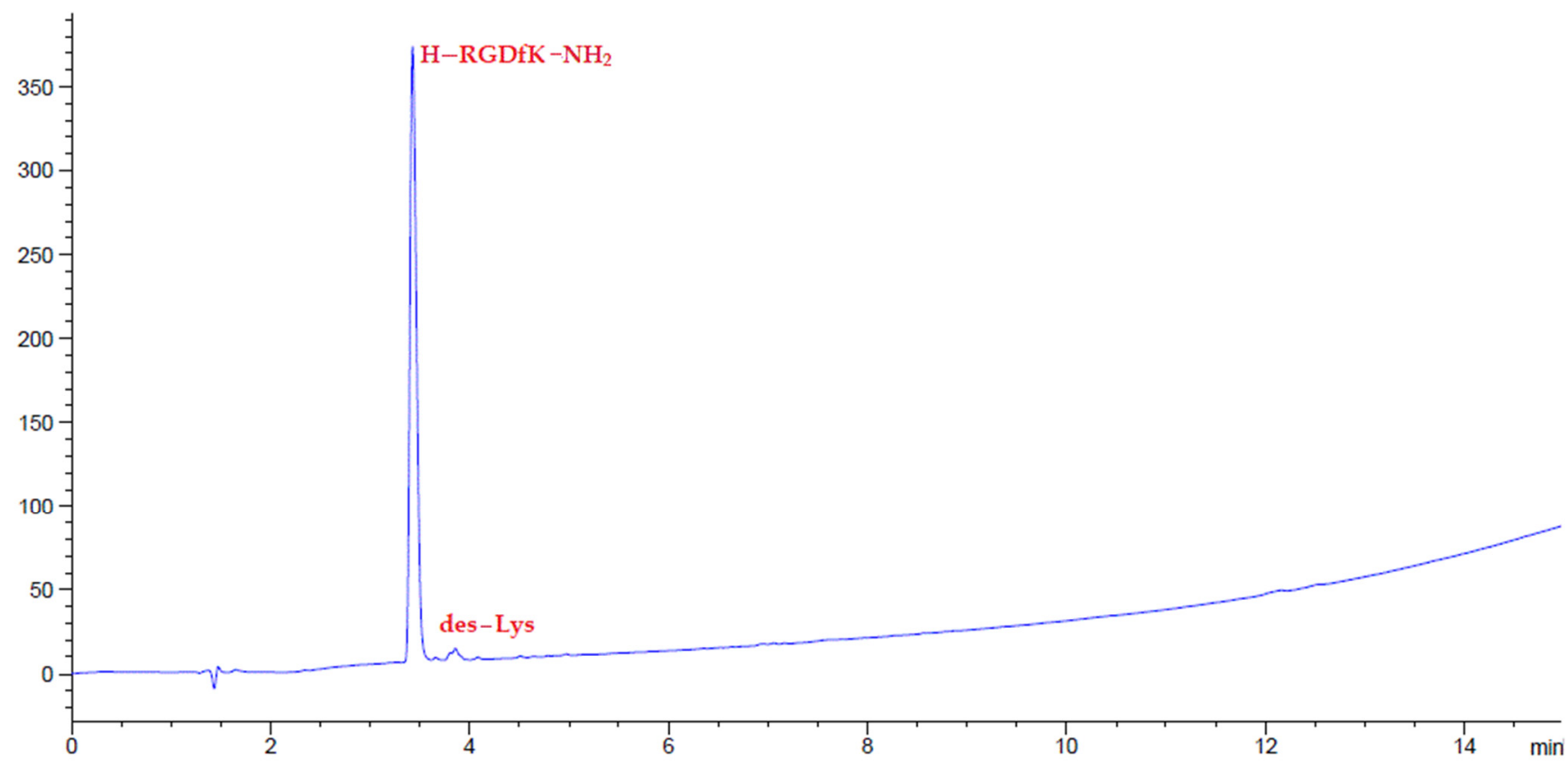

Figure 8. HPLC chromatograms of crude peptides H-RGDfK- $\mathrm{NH}_{2}$ after precipitation.

Amino-Li-resin was also tested with a modification of the difficult model peptide decaalanine [(Ala $)_{10}$ ] [52]. The modified [(Ala $)_{10}$ ] described herein is a 13-mer sequence (H-Ala-Ala-Ala-Ala-Ala-Ala-Ala-Ala-Ala-Ala-Lys-Lys-Lys- $\mathrm{NH}_{2}$ ) containing ten consecutive Ala and three Lys at the N-terminal added to help the solubility. Figure 10 shows the HPLC chromatogram of the crude peptide after mini cleavage to give the title compound with $87.7 \%$ purity, accompanied by the deletion of one, two, three, and four Ala as identified by mass spectroscopy. More serious deletions were observed for this difficult sequence by using other synthesis resins. The purity of this test synthesis by using amino-Li-resin is significantly better in comparison with the data obtained from using other resins [52]. 


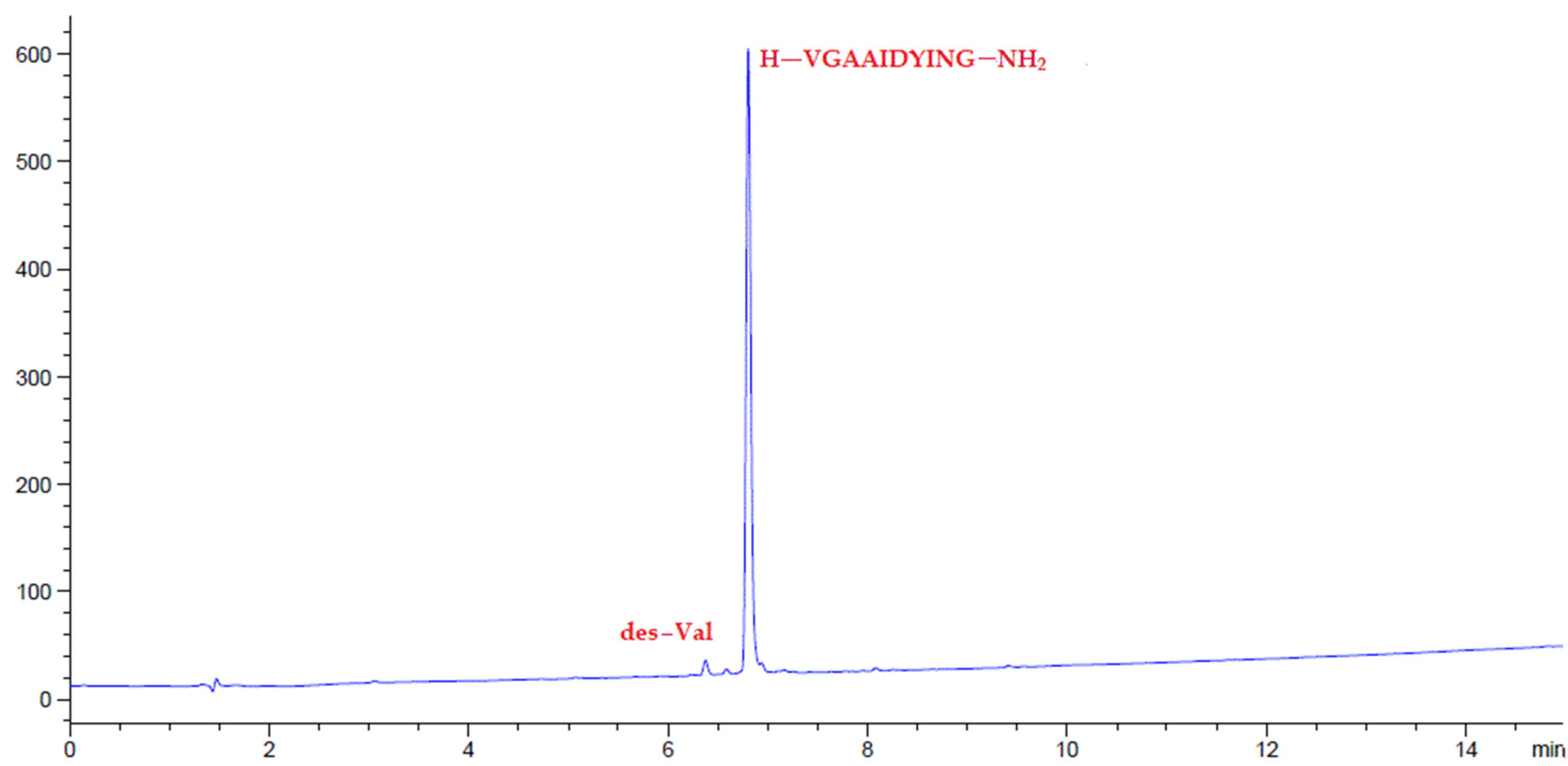

Figure 9. HPLC chromatograms of crude peptides H-VGAAIDYING-NH ${ }_{2}$ after precipitation.

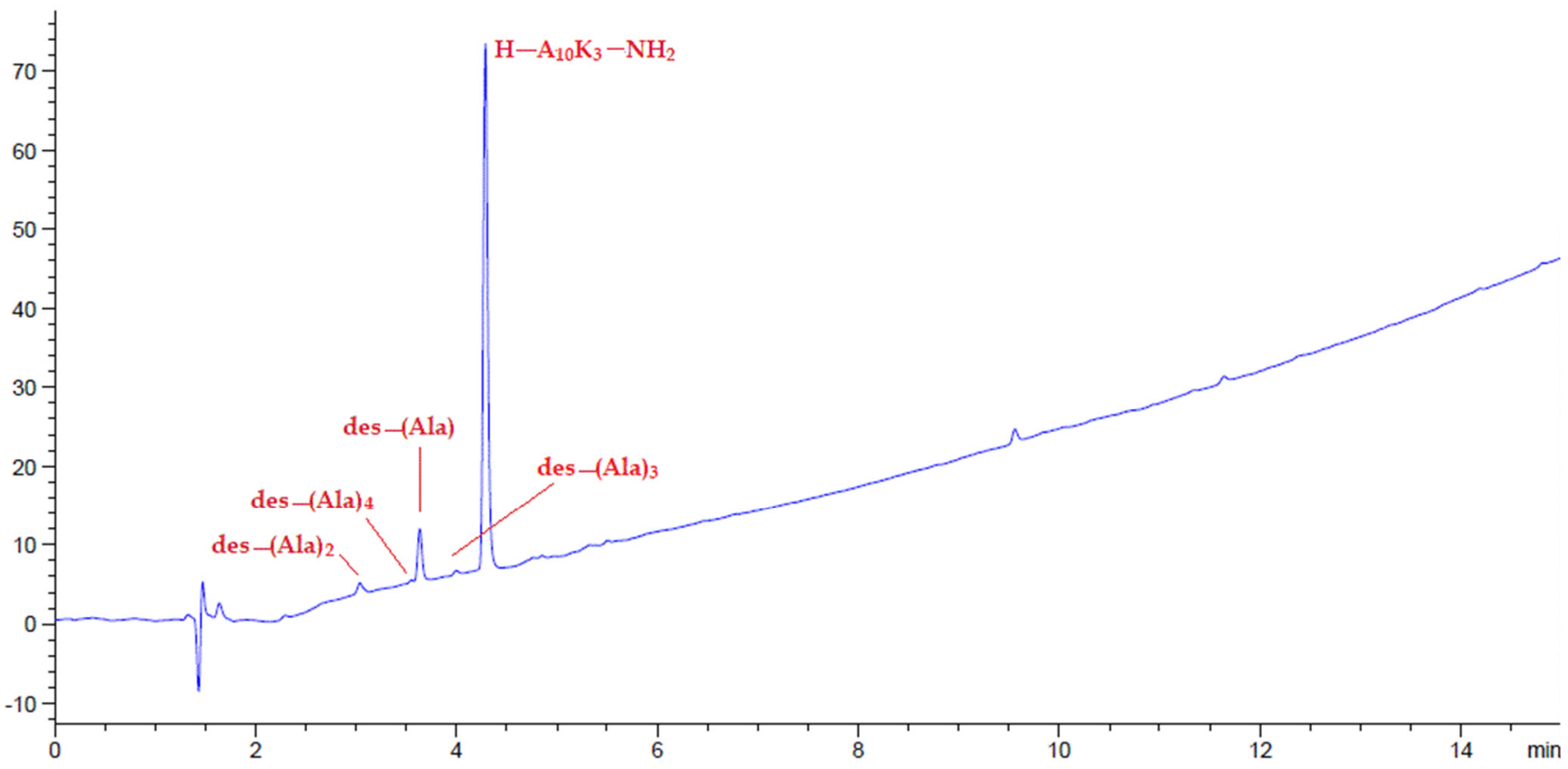

Figure 10. HPLC chromatograms of crude peptides $\mathrm{H}-(\mathrm{Ala})_{10}(\mathrm{Lys})_{3}-\mathrm{NH}_{2}$.

\section{Conclusions and Perspectives}

Amino-Li-resin is a new generation of polyacrylamide resin that is highly suitable for solid-phase chemistry. It has a high swelling capacity in a broad range of solvents, preferably in polar ones, but including those most used in SPPS and some of the green solvents used to work in a more sustainable environmental ecosystem. Of note, amino-Li-resin swells extremely well in $\mathrm{H}_{2} \mathrm{O}$ and alcohols of low molecular weight, thus making it highly suitable for biochemical applications such as the development of supports for affinity chromatography and the preparation of supported chemical libraries for on-resin screening. The rather highly cross-linked matrix confers the resin with excellent mechanical stability, which, along with its stability in the presence of a wide range of chemical reagents such as acids and bases, makes it particularly suitable for supported solid-phase organic synthesis. 
Unlike PS and other resins that are marketed in the form of beads, amino-Li-resin is in the form of fibers, thus maximizing surface area. Amino-Li-resin has a high functionalization $(0.8 \mathrm{mmol} / \mathrm{g})$, thereby conferring effectiveness in terms of peptide synthesized per gram of initial resin used. The absence of aromatic rings in amino-Li-resin should avoid the formation of $\pi-\pi$ interactions, which can favor resin collapse. The appropriateness of amino-Li-resin for SPPS has been demonstrated for the synthesis of several model peptides, including difficult sequences and hindered amino acids. The compatibility of amino-Li-resin with ACN could be very helpful for hindered couplings because it has been demonstrated that $\mathrm{ACN}$ is a good solvent for this kind of couplings.

More so, because the resin can swell very well in water, solid phase synthesis using water as solvent, or a co-solvent can be designed and conducted so that the process can be implemented in an environmentally friendly manner. Furthermore, because the resin is stable with extreme acidic or basic conditions, the biomolecules such as peptides can be synthesized and attached permanently to the resin. The resin, which swells well in water, opens a way to be used for affinity chromatography or even for direct immunization using peptide conjugated with the resin [53]. Overall, this novel resin overcomes the shortcomings of polystyrene resin and polyethylene glycol resin. The significance is that the resin can potentially become the resin of choice to replace both polystyrene resin and polyethylene glycol resin, streamlining the solid phase synthesis for its universal use.

\begin{abstract}
Author Contributions: Conceptualization, F.A., Y.L. and B.G.d.1.T.; methodology, D.C.A., B.G.d.1.T and F.A.; software, D.C.A., F.A. and B.G.d.1.T.; validation, D.C.A., Y.L., B.G.d.1.T. and F.A.; formal analysis, D.C.A.; investigation, D.C.A.; resources, Y.L., F.A. and B.G.d.1.T.; data curation, D.C.A.; writing - original draft preparation, D.C.A.; writing—review and editing, D.C.A., Y.L., B.G.d.l.T. and F.A.; visualization, D.C.A.; supervision, B.G.d.1.T. and F.A.; project administration, B.G.d.1.T. and F.A.; funding acquisition, B.G.d.l.T. and F.A. All authors have read and agreed to the published version of the manuscript.
\end{abstract}

Funding: The research was funded by the National Research Foundation (NRF) (Blue Sky's Research Programme \# 120386).

Institutional Review Board Statement: Not applicable.

Informed Consent Statement: Not applicable.

Data Availability Statement: The data presented in this study are available within the article.

Acknowledgments: The authors thank UKZN for an enabling environment for the research.

Conflicts of Interest: Yongfu $\mathrm{Li}$ is the inventor of the amino-Li-resin and is commercializing it through Biotide Core, LLC, USA. The rest of the authors declare no conflict of interest.

\title{
References
}

1. Merrifield, R.B. Solid Phase Peptide Synthesis. I. The Synthesis of a Tetrapeptide. J. Am. Chem. Soc. 1963, 85, 2149-2154. [CrossRef]

2. Lloyd-Williams, P.; Albericio, F.; Giralt, E. Chemical Approaches to the Synthesis of Peptides and Proteins, 1st ed.; CRC Press: Boca Raton, FL, USA, 1997. [CrossRef]

3. Zompra, A.A.; Galanis, A.S.; Werbitzky, O.; Albericio, F. Manufacturing peptides as active pharmaceutical ingredients. Future Med. Chem. 2009, 1, 361-377. [CrossRef] [PubMed]

4. Merrifield, B. Concept and early development of solid-phase peptide synthesis. Methods Enzymol. 1997, 289, 3-13. [CrossRef]

5. Ramkisson, S.; Jad, Y.E.; Sharma, A.; de la Torre, B.G.; Albericio, F. OctaGel Resin-A New PEG-PS-based Solid Support for Solid-Phase Peptide Synthesis. Lett. Org. Chem. 2019, 16, 935-940. [CrossRef]

6. García-Martín, F.; Quintanar-Audelo, M.; García-Ramos, Y.; Cruz, L.J.; Gravel, C.; Furic, R.; Côté, S.; Tulla-Puche, J.; Albericio, F. ChemMatrix, a poly (ethylene glycol)-based support for the solid-phase synthesis of complex peptides. J. Comb. Chem. 2006, 8, 213-220. [CrossRef] [PubMed]

7. Kates, S.A.; McGuinness, B.F.; Blackburn, C.; Griffin, G.W.; Solé, N.A.; Barany, G.; Albericio, F. "High-load" polyethylene glycol-polystyrene (PEG-PS) graft supports for solid-phase synthesis. Pept. Sci. 1998, 47, 365-380. [CrossRef]

8. Martin, V.; Jadhav, S.; Egelund, P.H.G.; Liffert, R.; Castro, H.J.; Krüger, T.; Haselmann, K.F.; Quement, S.T.L.; Albericio, F.; Dettner, F.; et al. Harnessing polarity and viscosity to identify green binary solvent mixtures as viable alternatives to DMF in solid-phase peptide synthesis. Green Chem. 2021, 23, 3295-3311. [CrossRef] 
9. Acosta, G.A.; del Fresno, M.; Paradis-Bas, M.; Rigau-DeLlobet, M.; Côté, S.; Royo, M.; Albericio, F. Solid-phase peptide synthesis using acetonitrile as a solvent in combination with PEG-based resins. J. Pept. Sci. 2009, 15, 629-633. [CrossRef]

10. Albericio, F.; Carpino, L.A. [7] Coupling reagents and activation. Methods Enzymol. 1997, 289, 104-126. [CrossRef]

11. Kamiński, Z.J.; Kolesińska, B.; Kolesińska, J.; Sabatino, G.; Chelli, M.; Rovero, P.; Błaszczyk, M.; Główka, M.L.; Papini, A.M. $\mathrm{N}$-Triazinylammonium tetrafluoroborates. A new generation of efficient coupling reagents useful for peptide synthesis. J. Am. Chem. Soc. 2005, 127, 16912-16920. [CrossRef]

12. Albericio, F.; Bofill, J.M.; El-Faham, A.; Kates, S.A. Use of Onium Salt-Based Coupling Reagents in Peptide Synthesis1. J. Org. Chem. 1998, 63, 9678-9683. [CrossRef]

13. Albericio, F. Orthogonal protecting groups for $\mathrm{N} \alpha$-amino and $\mathrm{C}$-terminal carboxyl functions in solid-phase peptide synthesis. Pept. Sci. 2000, 55, 123-139. [CrossRef]

14. Zervas, L.; Borovas, D.; Gazis, E. New methods in peptide synthesis. I. Tritylsulfenyl and o-nitrophenylsulfenyl groups as N-protecting groups. J. Am. Chem. Soc. 1963, 85, 3660-3666. [CrossRef]

15. Ramage, R.; Hopton, D.; Parrott, M.J.; Kenner, G.W.; Moore, G.A. Phosphinamides: A new class of amino protecting groups in peptide synthesis. J. Chem. Soc. Perkin Trans. 1984, 1, 1357-1370. [CrossRef]

16. Kenner, G.; Moore, G.; Ramage, R. Phosphinamides-a new class of amino protecting groups in peptide chemistry. Tetrahedron Lett. 1976, 17, 3623-3626. [CrossRef]

17. Neumann, K.; Farnung, J.; Baldauf, S.; Bode, J.W. Prevention of aspartimide formation during peptide synthesis using cyanosulfurylides as carboxylic acid-protecting groups. Nat. Commun. 2020, 11, 982. [CrossRef] [PubMed]

18. Paradís-Bas, M.; Tulla-Puche, J.; Albericio, F. 2-Methoxy-4-methylsulfinylbenzyl: A backbone amide safety-catch protecting group for the synthesis and purification of difficult peptide sequences. Chem. Eur. J. 2014, 20, 15031-15039. [CrossRef] [PubMed]

19. Bedford, J.; Hyde, C.; Johnson, T.; Jun, W.; Owen, D.; Quibell, M.; Sheppard, R.C. Amino acid structure and "difficult sequences" in solid phase peptide synthesis. Int. J. Pept. Protein Res. 1992, 40, 300-307. [CrossRef]

20. Atherton, E.; Clive, D.L.J.; Sheppard, R.C. Polyamide supports for polypeptide synthesis. In Peptides 1971: Proceedings of the 11th European Peptide Symposium; North Holland Publishing Co.: Amsterdam, The Netherlands, 1973; p. 111.

21. Atherton, E.; Clive, D.L.; Sheppard, R.C. Polyamide supports for polypeptide synthesis. J. Am. Chem. Soc. 1975, 97, 6584-6585. [CrossRef]

22. Arshady, R.; Atherton, E.; Gait, M.J.; Lee, K.; Sheppard, R.C. Easily prepared polar support for solid phase peptide and oligonucleotide synthesis. Preparation of substance P and a nonadeoxyribonucleotide. J. Chem. Soc. Chem. Commun. 1979, 9, 423-425. [CrossRef]

23. Heidmann, W.; Köster, H. Festphasensynthese von oligonucleotiden, 11. Verwendung eines neuartigen hydrophilen perlpolymerisats als träger. Makromol. Chem. 1980, 181, 2495-2506. [CrossRef]

24. Arshady, R.; Atherton, E.; Clive, D.L.; Sheppard, R.C. Peptide synthesis. Part 1. Preparation and use of polar supports based on poly (dimethylacrylamide). J. Chem. Soc. Perkin Trans. 1981, 529-537. [CrossRef]

25. Arshady, R. Development of new hydrophilic polymer supports based on dimethylacrylamide. Colloid. Polym. Sci. 1990, 268, 948-958. [CrossRef]

26. Atherton, E.; Logan, C.J.; Sheppard, R.C. Peptide synthesis. Part 2. Procedures for solid-phase synthesis using N $\alpha$-fluorenylmethoxycarbonylamino-acids on polyamide supports. Synthesis of substance P and of acyl carrier protein 65-74 decapeptide. J. Chem. Soc. Perkin Trans. 1981, 538-546. [CrossRef]

27. Kanda, P.; Kennedy, R.C.; Sparrow, J.T. Synthesis of polyamide supports for use in peptide synthesis and as peptide-resin conjugates for antibody production. Int. J. Pept. Protein Res. 1991, 38, 385-391. [CrossRef] [PubMed]

28. Sparrow, J.T.; Knieb-Cordonier, N.G.; Obeyseskere, N.U.; McMurray, J.S. Large-pore polydimethylacrylamide resin for solid-phase peptide synthesis: Applications in Fmoc chemistry. Pept. Res. 1996, 9, $297-304$.

29. Zalipsky, S.A.; Albericio, F.; Barany, G. Peptides: Structure and Function: Proceedings of the Ninth American Peptide Symposium; Deber, C.M., Hruby, V.J., Kopple, K.D., Eds.; Pierce Chemical Company: Rockford, IL, USA, 1985; pp. $257-260$.

30. Bayer, E.H.; Albert, K.; Rapp, W.; Dengler, M. Peptides, Structure and Function: Proceedings of the Eighth American Peptide Symposium; Hruby, V.J., Rich, D.H., Eds.; Pierce Chemical Company: Rockford, IL, USA, 1983; pp. 87-90.

31. Rapp, W. Combinatorial Peptide and Nonpeptide Libraries: A Handbook; Jung, G., Ed.; VCH: Weinheim, Germany, 1996; pp. 425-464.

32. Adams, J.H.; Cook, R.M.; Hudson, D.; Jammalamadaka, V.; Lyttle, M.H.; Songster, M.F. A Reinvestigation of the Preparation, Properties, and Applications of Aminomethyl and 4-Methylbenzhydrylamine Polystyrene Resins1. J. Org. Chem. 1998, 63, 3706-3716. [CrossRef]

33. Gooding, O.W.; Baudart, S.; Deegan, T.L.; Heisler, K.; Labadie, J.W.; Newcomb, W.S.; Porco, J.A., Jr.; van Eikeren, P. On the development of new poly (styrene-oxyethylene) graft copolymer resin supports for solid-phase organic synthesis. J. Comb. Chem. 1999, 1, 113-122. [CrossRef]

34. Auzanneau, F.I.; Meldal, M.; Bock, K. Synthesis, characterization and biocompatibility of PEGA resins. J. Pept. Sci. 1995, 1, 31-44. [CrossRef]

35. Meldal, M. Pega: A flow stable polyethylene glycol dimethyl acrylamide copolymer for solid phase synthesis. Tetrahedron Lett. 1992, 33, 3077-3080. [CrossRef]

36. Meldal, M. Properties of solid supports. Methods Enzymol. 1997, 289, 83-104. [CrossRef] [PubMed] 
37. Darlak, K.; Wiegandt Long, D.; Czerwinski, A.; Darlak, M.; Valenzuela, F.; Spatola, A.; Barany, G. Facile preparation of disulfidebridged peptides using the polymer-supported oxidant CLEAR-OXTM. J. Pept. Res. 2004, 63, 303-312. [CrossRef]

38. Kempe, M.; Barany, G. CLEAR: A novel family of highly cross-linked polymeric supports for solid-phase peptide synthesis ${ }^{1,2}$. J. Am. Chem. Soc. 1996, 118, 7083-7093. [CrossRef]

39. Tulla-Puche, J.; Barany, G. On-Resin Native Chemical Ligation for Cyclic Peptide Synthesis ${ }^{1,2}$. J. Org. Chem. 2004, 69, $4101-4107$. [CrossRef] [PubMed]

40. Rademann, J.; Grøtli, M.; Meldal, M.; Bock, K. SPOCC: A resin for solid-phase organic chemistry and enzymatic reactions on solid phase. J. Am. Chem. Soc. 1999, 121, 5459-5466. [CrossRef]

41. Renil, M.; Meldal, M. POEPOP and POEPS: Inert polyethylene glycol crosslinked polymeric supports for solid synthesis. Tetrahedron Lett. 1996, 37, 6185-6188. [CrossRef]

42. Cote, S. New Polyether Based Monomers and Highly Cross-Linked Amphiphile Resins. Patent WO 2005012277, 10 February 2005.

43. García-Martín, F.; White, P.; Steinauer, R.; Côté, S.; Tulla-Puche, J.; Albericio, F. The synergy of ChemMatrix resin ${ }^{\circledR}$ and pseudoproline building blocks renders Rantes, a complex aggregated chemokine. Pept. Sci. 2006, 84, 566-575. [CrossRef]

44. García-Ramos, Y.; Paradís-Bas, M.; Tulla-Puche, J.; Albericio, F. ChemMatrix ${ }^{\circledR}$ for complex peptides and combinatorial chemistry. J. Pept. Sci. 2010, 16, 675-678. [CrossRef]

45. Kijewska, M.; Nuti, F.; Wierzbicka, M.; Waliczek, M.; Ledwoń, P.; Staśkiewicz, A.; Real-Fernandez, F.; Sabatino, G.; Rovero, P.; Stefanowicz, P. An Optimised Di-Boronate-ChemMatrix Affinity Chromatography to Trap Deoxyfructosylated Peptides as Biomarkers of Glycation. Molecules 2020, 25, 755. [CrossRef]

46. Santini, R.; Griffith, M.C.; Qi, M. A measure of solvent effects on swelling of resins for solid phase organic synthesis. Tetrahedron Lett. 1998, 39, 8951-8954. [CrossRef]

47. Sabbagh, F.; Muhamad, I.I. Physical and Chemical Characterisation of Acrylamide-Based Hydrogels, Aam, Aam/NaCMC and Aam/NaCMC/MgO. J. Inorg. Organomet. Polym. Mater. 2017, 27, 1439-1449. [CrossRef]

48. Yraola, F.; Ventura, R.; Vendrell, M.; Colombo, A.; Fernàndez, J.C.; de la Figuera, N.; Fernández-Forner, D.; Royo, M.; Forns, P.; Albericio, F. A Re-evaluation of the Use of Rink, BAL, and PAL Resins and Linkers. QSAR Comb. Sci. 2004, 23, 145-152. [CrossRef]

49. Martínez-Ceron, M.C.; Marani, M.M.; Taulés, M.; Etcheverrigaray, M.; Albericio, F.; Cascone, O.; Camperi, S.A. Affinity chromatography based on a combinatorial strategy for rerythropoietin purification. ACS Comb. Sci. 2011, 13, 251-258. [CrossRef] [PubMed]

50. Al Musaimi, O.; Beatriz, G.; Albericio, F. Greening Fmoc/t Bu solid-phase peptide synthesis. Green Chem. 2020, 22, 996-1018. [CrossRef]

51. Hamdan, F.; Bigdeli, Z.; Balalaie, S.; Sewald, N.; Michalek, C. Efficient synthesis of novel RGD based peptides and the conjugation of the pyrazine moiety to their N-terminus. New J. Chem. 2019, 43, 2702-2709. [CrossRef]

52. Kates, S.A.; Solé, N.A.; Beyermann, M.; Barany, G.; Albericio, F. Optimized preparation of deca(L-alanyl)-L-valinamide by 9-fluorenylmethyloxycarbonyl (Fmoc) solid-phase synthesis on polyethylene glycol-polystyrene (PEG-PS) graft supports, with 1,8-diazobicyclo [5.4.0]-undec-7-ene (DBU) deprotection. Pept. Res. 1996, 9, 106-113.

53. Fischer, P.M.; Comis, A.; Howden, M.E.H. Direct immunization with synthetic peptidyl-polyamide resin: Comparison with antibody production from free peptide and conjugates with carrier proteins. J. Immunol. Methods 1989, 118, 119-123. [CrossRef] 